\title{
PREDICTING DIFFICULT INTUBATION IN SURGICAL PATIENTS SCHEDULED FOR GENERAL ANAESTHESIA: A PROSPECTIVE STUDY OF 435 PATIENTS
}

Udita Naithani, Ganesh Gupta, Keerti, Monika Gupta, Khemraj Meena, C. P. Sharma, Pramila Bajaj

\author{
1. Associate Professor. Department of Anaesthesia, RNT Medical College. Udaipur. Rajasthan. \\ 2. Senior Resident, Department of Anaesthesia, Geetanjali Medical College. Udaipur. Rajasthan. \\ 3. Associate Professor. Department of PSM, RNT Medical College. Udaipur. Rajasthan. \\ 4. PG Student, Department of Anaesthesia, RNT Medical College. Udaipur, Rajasthan. \\ 5. Associate Professor. Department of Anaesthesia, RNT Medical College. Udaipur. Rajasthan. \\ 6. Sr. Resident, Department of PSM, RNT Medical College. Udaipur, Rajasthan. \\ 7. Professor. Department of Anaesthesia, Geetanjali Medical College. Udaipur. Rajasthan.
}

\section{CORRESPONDING AUTHOR:}

Dr. Udita Naithani,

II- 238, OTC, Charak Marg,

Udaipur- 313001.

E-mail: drvinaynaithani@gmail.com,moniks111@gmail.com

ABSTRACT: BACKGROUND: Unanticipated difficult tracheal intubation is a significant source of morbidity and mortality in anaesthetic practice which can be reduced by identification of potential difficult intubation. OBJECTIVE: We aimed the present study to know the incidence of difficult intubation, factors associated with it and the predictive value of various airway predictors in anticipating difficult visualization of larynx and difficult intubation. METHODS: 435 adult patients (>18 year) undergoing general anaesthesia with intubation were examined preoperatively for demographic details (age, sex, weight), dentition, airway pathology and six airway predictors i.e. Inter Incisor Gap (IIG), Modified Mallampatti Grading (MMPG), Upper lip bite test (ULBT), Thyromental distance (TMD), Sternomental distance (SMD) and subluxation of mandible (SLM). All patients were anaesthetized using standard protocol with thiopentone $(5 \mathrm{mg} / \mathrm{kg})$ and succinylcholine $(1.5 \mathrm{mg} / \mathrm{kg})$. On direct laryngoscopy, Cormack Lehane (CL) grading was noted. CL grade I, II was defined as easy visualization of larynx (EVL) and CL grade III, IV as difficult visualization of larynx (DVL). Difficult intubation score (DIS) was calculated as sum of CL grade and number of intubation attempts. DIS of less than or equal to 4 was defined as easy intubation (EI) and DIS > 4 was defined as difficult intubation (DI).Sensitivity, specificity, positive and negative predictive value, positive and negative likelihood ratios(LR) and odd's ratio value for six airway predictor tests was calculated by standard formulae. RESULTS: Incidence of DVL was $12.65 \%(n=55)$ and DI was $9.65 \%(n=42)$, with no failed intubation. All airway tests had very high negative predictive value $(>90 \%)$ which implicates they identify easy intubations more precisely. MMPG and ULBT were found as nearly perfect airway predictors for difficult intubation having odds ratio of 85.23 (95\% CI 25.42- 285.89\%) and 65.45 (95\% CI $25.69-166.7 \%)$ respectively, along with very high sensitivity of $92.80 \%$ and $85.7 \%$ respectively. Presence of ULBT III is the best predictor of difficult intubation (+LR 21.97) and absence of MMPG III, IV is the best predictor of difficult intubation (-LR 0.091). Abnormal dentition and airway pathology also increase the risk of difficult intubation, $\mathrm{P}<0.001$.

CONCLUSION: We conclude that ULBT and MMPG are "nearly perfect" airway predictors and should be used routinely during pre-anesthetic visit for screening of difficult intubation. 
KEYWORDS: difficult intubation, difficult laryngoscopy, airway predictors, failed intubation, ULBT, MMPG, difficult intubation score.

INTRODUCTION: Airway management and endotracheal intubation are fundamental skills for the safe conduct of anaesthesia. The American Society of Anaesthesiologists Task Force on management of difficult airways states "an experienced anaesthetist who feels difficulty in bag mask ventilation, laryngoscopy or endotracheal intubation or both is called difficult airway"1. The incidence of difficult intubation in operating room has been reported to range from $1 \%$ to $18 \%{ }^{2}$. The incidence of abandoned/ failed intubation is approximately $0.05 \%-0.35 \%, 4$, whereas that of cannot ventilate by mask, cannot intubate is around $0.0001 \%-0.02 \% 5$.

Difficulty in intubation is usually associated with difficulty in exposing the glottis by direct laryngoscopy. This involves a series of maneuvers like extending the head, opening the mouth, displacing and compressing the tongue into the submandibular space and lifting the mandible forward. The ease or difficulty in performing each of these maneuvers can be assessed by one or more parameters ${ }^{6}$.

The most common of these tests are Mallampati criteria ${ }^{7}$ later on modified by Samsoon and Young 3 , thyromental distance ${ }^{8}$, sternomental distance, receding mandible, buck teeth, obesity, degree of head extension, interincisor gap, grading of prognathism, mandibular ramus length etc. 9,10 Initial studies tried to compare individual parameters to predict difficult intubation with mixed results. ${ }^{3,7}$ Later studies have attempted to create a scoring system like Wilson's index ${ }^{11}$ and multifactorial clinical index.12,13 In 2003, Khan et al proposed a new test the Upper Lip Bite Test (ULBT) which involves assessment of jaw subluxation and presence of buck teeth in single test. ${ }^{14}$

We carried out the present study to know the incidence of difficult intubation and to assess the predictive value of various airway predictors and demographic factors in anticipating difficult visualization of larynx and difficult intubation with an ultimate aim that if all the difficult airways could be predicted confidently preoperatively, then the best possible route of tracheal intubation or establishing airway could be planned, hence obviating the possible direct consequences of failed intubation.

MATERIAL AND METHODS: After obtaining approval from the ethical review committee, the present study was conducted at a teaching hospital of Rajasthan, India. Informed consent was taken from 435 study patients ( $\geq 18$ years) of either sex, scheduled to receive general anesthesia requiring tracheal intubation for various surgeries (abdominal, gynecological, obstetric, urological, neuro-surgery, eye, cardiothoracic, orthopedic, ENT and plastic surgeries).

Sample size was calculated for a cross sectional descriptive study using random sampling by Epi info 6. Our population size is six thousand (i.e expected number of adult patients undergoing surgery in general anaesthesia with endotracheal intubation in one year period). Expected number of difficult intubation $1.5-13 \%$ has been reported ${ }^{5}$. With confidence level of $80 \%$, sample size was 435 . Three separate anaesthesiologists having experience of intubation of 2 years were involved in the study to avoid bias. One collected preoperative data of all the patients, another performed all tracheal intubations and recorded Cormack Lehane grading and third recorded intubation data. During the one year study period, intubating anesthesiologist was posted in different operation theaters and to ensure random sampling, all the cases he was going to intubate, were included in the study till sample size of 435 was achieved. 
Pre operative data recording: All patients were examined preoperatively for demographic details (age, sex, weight), dentition, airway pathology and six bed side airway tests ${ }^{9}$ that can be easily performed were measured -

i. Mouth opening (inter incisor gap, IIG): The patient was asked to open the mouth as wide as possible and the distance between upper and lower incisors was measured with a scale; inter incisor gap less than $4 \mathrm{~cm}$ predicts difficult laryngoscopy.

ii. Modified Mallampati test (MMPG): The patient was in a sitting posture with the head in neutral position and was asked to open the mouth fully and protrude the tongue maximally without phonating. Now the examiner observed the pharyngeal structures from front of the patient with pen torch and the view was graded as: I- Soft palate, uvula and pillars visible; IISoft palate, uvula visible and pillars invisible; III - Soft palate and base of uvula visible; IV- Soft palate invisible. Grade III and IV are predicted as difficult intubation.

iii. Upper lip bite test (ULBT): Class-I: Lower incisors can bite the upper lip above the vermilion line; Class-II: Lower incisors can bite the upper lip below the vermilion line; Class-III: Lower incisors cannot bite the upper lip. Class-III predicts difficult intubation.

iv. Sternomental distance (SMD): It is measured in sitting position with the head fully extended on the neck and the mouth closed. Straight distance between the upper border of manubrium sterni and bony point of the mentum is measured. SMD $<13.5 \mathrm{~cm}$ is considered as predictor of difficult intubation.

v. Thyromental distance (TMD): The patient should be seated upright and asked to extend his/her head and neck as far as possible with mouth closed. The straight distance of the exterior surface from the inside of the mentum to thyroid notch is measured. Distance equal or less than $6.5 \mathrm{~cm}$ predicts difficult intubation.

vi. Subluxation of mandible (SLM): The patient is asked to protrude his/her lower incisor as far as possible and protrusion is ranked as: 1 - Lower incisor anterior to upper incisor; 2 Lower incisor not anterior to upper incisor; 3 - Lower incisor fail to reach to upper incisor. Rank 3 is predicted as difficult intubation.

METHOD OF ANAESTHESIA: Following application of standard ASA monitoring, patients were premedicated with glycopyrrolate $0.2 \mathrm{mg}$, ondansetron $4 \mathrm{mg}$ and tramadol $100 \mathrm{mg}$. After 3 minutes of preoxygenation, anaesthesia was induced with $5 \mathrm{mg} / \mathrm{kg}$ sodium thiopental and suxamethonium $1.5 \mathrm{mg} / \mathrm{kg}$ i.v. The patient's head was placed in sniffing position and laryngoscopy was performed using a Macintosh blade and glottic view was noted using Cormack Lehane's classification, then intubation was attempted. Adjuvant manoeuvres such as optimum external laryngeal pressure (OELM) or upward pressure on the epiglottis with the tip of the blade or both; intubating stylet or McCoy's blade were used to facilitate intubation, if required. When the first attempt failed, further attempts were performed by another senior anaesthetist using the same technique and deepening anaesthesia, if warranted, and mask ventilation between intubation attempts, to avoid hypoxia. If patient could not be intubated in three attempts, it was considered as failed intubation and LMA size 3/4 was placed to maintain airway.

Points noted during intubation included: Whether external laryngeal pressure applied, best view of laryngoscopy according to Cormack Lehane's classification, number of attempts and use of stylet or McCoy's blade.

Definition of difficult laryngoscopic intubation was based on the best laryngoscopic view and number of laryngoscopy attempts; since it has been shown that using both these 
parameters improve the reliability of identification of difficult laryngoscopic tracheal intubation ${ }^{10}$. The view at laryngoscopy was graded by Cormack Lehane's method in the following manner: I - Complete vocal cords visible; II - Only posterior commissure or arytenoids visible; III - Only epiglottis visible; IV - None of the foregoing visible (not even the epiglottis). Cormack Lehane grades I, II were defined as Easy Visualization of larynx (EVL) and predict easy intubation. Grade III and IV were defined as difficulty in visualization of Larynx (DVL) and predict difficult intubation.

Difficult intubation was defined by Difficult Intubation Score (DIS) described by Aftab et al10 which was calculated by adding number of laryngoscopy attempts and grade of laryngoscopy. A score $<4$ or 4 was taken as easy intubation (EI) and a score $>4$ as difficult intubation (DI). ${ }^{10}$

To avoid observer bias, an independent observer anesthesiologist noted number of attempts, the lowest $\mathrm{SpO}_{2}$ level during intubation, and complications occurring during laryngoscopy and intubation like haemodynamic disturbances, arrhythmia, bucking etc.

STATISTICAL ANALYSIS: Continuous variables were expressed as mean \pm standard deviation. Non-continuous variables were expressed as the number of occurrence and percentage. The association between different variables and difficulty in laryngoscopy and intubation (DVL and DI) were evaluated using the chi-square test and Fisher's exact test for qualitative data and student ' $\mathrm{t}$ ' test for quantitative data. $\mathrm{P}<0.05$ was regarded as significant. Data were entered and analyzed with the help of Excel and Epi Info 6.

Specificity, sensitivity, positive and negative predictive value, positive and negative likelihood ratio and odds ratio for each airway predictor were calculated according to standard formula. Statistical terminologies used in our study are:

True Positive (TP): Difficult intubation that had been predicted to be difficult. False Positive (FP): Easy intubation that had been predicted to be difficult. True Negative (TN): Easy intubation that had been predicted to be easy.

False Negative (FN): Difficult intubation that had been predicted to be easy.

Sensitivity: The percentage of correctly predicted difficult intubation as a proportion of all intubations which were truly difficult $=\mathrm{TP} / \mathrm{TP}+\mathrm{FN}$

Specificity: The percentage of correctly predicted easy intubations as a proportion of all intubations which were truly easy $=\mathrm{TN} / \mathrm{TN}+\mathrm{FP}$

Positive predictive value (PPV): The percentage of correctly predicted difficult intubations as a proportion of all predicted difficult intubations $=\mathrm{TP} / \mathrm{TP}+\mathrm{FP}$

Negative predictive value (NPV): The percentage of correctly predicted easy intubations as a proportion of all predicted easy intubations $=\mathrm{TN} / \mathrm{TN}+\mathrm{FN}$

Positive likelihood ratio (+LR): Sensitivity/ 1 - Specificity

Negative likelihood ratio (-LR): 1 - Sensitivity/ Specificity

Odds ratio (OR): It is used to assess the risk of a particular outcome (difficult intubation) if a certain factor (factor predicting difficult) is present. For calculating odds ratio a $2 \times 2$ table is constructed in following manner.

\begin{tabular}{|l|l|l|}
\hline & Difficult Intubation & Easy Intubation \\
\hline Predict Difficult & True Positive (a) & False Positive (b) \\
\hline Predict Easy & False Negative (c) & True Negative (d) \\
\hline
\end{tabular}


O.R. is calculated as:

$\mathrm{OR}=\frac{\text { True Positive } \mathrm{x} \text { True Negative }}{\text { False Positive } \mathrm{x} \text { False Negative }}=\frac{\mathrm{a} \times \mathrm{d}}{\mathrm{b} \times \mathrm{c}}$

Interpretation of the magnitude of a correlation in terms of percentage is difficult, but in qualitative terms like trivial, small, moderate and large is easy. Therefore, when we discuss the results of any effect statistics, a scale using these qualitative terms is needed. Hopkin's $(2000)^{15}$ adopted a Likert scale like approach and gave a 'complete scale' which is applicable to interpret the magnitude of a correlation and odds ratio. We have used this complete scale in our study to interpret the results of sensitivity, specificity, negative and positive predictive values [range from 0 to $100 \%$ or ( 0 to 1 )] and odds ratio (range from 0 to infinite) as shown in Fig 1, 2.

RESULTS: We examined 435 patients $\{202$ (46.5\%) males, 233 (53.5\%) females $\}$ aged 18 to 80 years, weighing 38 to $96 \mathrm{~kg}$. Difficulty in visualization of larynx (i.e. CL grade III, IV) was encountered in $55(12.65 \%)$ patients and difficult intubation (i.e. DIS > 4) occurred in 42 $(9.65 \%)$ patients. There was no failed intubation. There was no statistically significant association between difficulty in intubation (DI) and age, sex or weight of the patients $(\mathrm{P}>0.05)$, (Table 1).

CL I, II were found to have significant association with easy intubation, $\mathrm{P}=0.000$. There was a significant increase in the need of OLEM to visualize larynx and number of intubation attempts in patients with CL III, IV, $\mathrm{P}=0.000$, Table 2.

Abnormal dentition i.e. bucked or missing teeth, airway pathology (Table 3) and use of nasotracheal or flexometallic tracheal tube were found as risk factors for difficult intubation, $\mathrm{P}=0.004$.

Among airway tests, presence of IIG $<4$, MMPG III, IV, ULBT III, TMD $<6.5$ and SLM class III had significant association with DVL and DI, $\mathrm{p}<0.05$. Incidence of DVL and DI was also higher in patient with $\mathrm{SMD}<13.5$ but it could not reach statistical significance (table 4).

The tests which have high sensitivity are good predictors to identify difficult intubation (true positive) and can be used for screening. We found MMPG and ULBT as good predictors for screening of difficult intubation with sensitivity of $92.8 \%$ and $85.7 \%$ respectively.

The tests which have high specificity are confirmatory. They identify easy intubation (true negative) specifically. In our study IIG, ULBT, SMD had specificity of $>90 \%$ means presence of IIG $>4 \mathrm{~cm}$, ULBT class I, II and SMD $>13.5 \mathrm{~cm}$ indicate easy intubation.

High positive predictive value correctly predicts difficult intubation. In our study, only ULBT has high positive predictive value (92.3\%) means presence of ULBT III can predict higher proportion of difficult intubations.

High negative predictive value identifies correctly predicted easy intubation. Almost all the tests in our study had very high negative predictive value which shows that patient having IIG $>4 \mathrm{~cm}$, ULBT I,II, MMPG I,II, SLM I,II, TMD $>6.5 \mathrm{~cm}$, SMD $>13.5 \mathrm{~cm}$ will have high proportion of easy intubation. (Table 5, Fig 1)

Accuracy of airway predictors was further analysed by likelihood ratio and odds ratio. Likelihood ratio greater than 10 and less than 0.1 are considered strong evidence for ruling in or ruling out diagnosis respectively, under most circumstances ${ }^{2}$. Likelihood ratio for a positive result indicates how many times the difficult intubation is more likely if it is predicted difficult with a particular airway predictor. 
In our study, only ULBT had positive likelihood ratio of $>10$, i.e. 21.97 which indicates that presence of ULBT III is the best predictor of difficult intubation. If negative likelihood ratio (-LR) is $<0.1$, it rules out difficult intubation. In our study only MMPG had negative likelihood ratio of 0.091 which means that absence of MMPG III \& IV will rule out the difficult intubation (Table 5).

The odds ratio is a relative measure of risk telling us how much more likely it is that someone who is exposed to the factor under study will develop the outcome as comparable to someone who is not exposed. An odds ratio of 1 tells no association between exposure and outcome and we graded odds ratio according to complete scale by Hopkins ${ }^{15}$. ULBT and MMPG were found as "nearly perfect" airway predictors for difficult intubation with odds ratio of 65.45 (95\% CI 25.69 - 166.7\%) and 85.23 (95\% CI 25.42 - 285.89\%) respectively. It implicates that patient having ULBT class III and MMPG class III, IV will more likely to have risk of difficult intubation (Table 5, Fig 2).

DISCUSSION: Worldwide, upto 600 patients are thought to die annually as a result of complications occurring at the time of tracheal intubation ${ }^{16}$. Approximately $30 \%$ of the deaths in patients who experienced difficulties at laryngoscopy or intubation are caused by hypoxic brain damage secondary to inability to maintain a patent airway ${ }^{17}$. In an American Society of Anaesthesiologists closed - claims analysis, increase in the incidence of morbid non fatal events have also been noted in patients who have undergone difficult tracheal intubation ${ }^{18}$. These events included desaturation, hypertension, esophageal intubation, pharyngeal trauma, dental injury, cancellation of surgery, increased hospital stay and an increased rate of unexpected intensive care unit admission. ${ }^{19}$

Most of the studies $20-25$ used CL Grade III, IV to define difficult intubation and some used intubation difficulty scale (IDS) ${ }^{26-28}$. We described difficulty in visualisation of larynx (DVL) as CL III,IV and difficult intubation (DI) as DIS $>4$, described by Aftab et al ${ }^{10}$. In our study, incidence of DVL was $12.65 \%$ and DI was $9.65 \%$, there was no failed intubation. Lee (2006) ${ }^{29}$ conducted a meta analysis involving a literature search of 42 studies that enrolled 34513 patients in which the prevalence of difficult intubation ranged from $6 \%$ to $13 \%$. Another meta analysis by Shiga et al (2005)2 involved 35 studies (50,760 patients) from electronic data base and the overall incidence of difficult intubation was 5.8\% (95\% confidence interval, 4.5-7.5\%).

Older age ${ }^{12,30}$, male sex ${ }^{30}$ and obestiy ${ }^{28,31}$ have been reported as risk factors for difficult intubation. Advanced age means decreased neck mobility, increased articulations, stiffness, irregular teeth position and morphology 12,30 whereas increased muscle mass and neck rigidity occur more in males than in females ${ }^{30}$.

Intubation difficulty Score (IDS) were found to be higher among obese patients because of poor glottic exposure, need of increased lifting force during laryngoscopy and external laryngeal pressure to improve glottic exposure ${ }^{28,31}$. The airway of obese patients may be narrowed, and difficulty with mask ventilation and tracheal intubation might be expected due to the increased bulk of soft tissue as a result of fat tissue accumulation in the cheeks, palate, pharynx, and airway. Furthermore, large breasts, short neck, restricted mouth opening and limitation of flexion and extension of cervical spine and atlanto-occipital joint all contribute to this situation ${ }^{32}$. Nevertheless, many authors ${ }^{9,12,23,24}$ found no correlation between difficult intubation and age, sex and weight, which is in concordance to present study. Turkan et al ${ }^{33}$ had an idea that the predictive parameters should be reconsidered in the context of age and sex. Study population of present study was generalised in which only $6.5 \%$ were aged $>65 \mathrm{yr}$ and 
$2.3 \%$ were $>90 \mathrm{~kg}$. So, effect of advanced age and obestiy on difficult intubation could not be delineated.

Abnormal dentition i.e. bucked or multiple missing teeth was found as a significant risk factor for difficult intubation in our study. The presence of upper front teeth is mentioned as independent risk factor for difficult intubation 34,35. Missing teeth make the laryngoscopy difficult as the blade enters in the space and various adjuvants have been described to fill this space. However, some authors reported no association of tooth morphology with difficult intubation ${ }^{12}$. We observed that presence of airway pathology like Ludwig angina, fracture mandible, cervical collar, post burn contracture neck, large thyroid goiter increase the risk of difficult intubation. Arne et al $^{12}$ generated a multivariate index $(0-48)$ in which presence of airway pathology has ' 5 ' points. Patients with occipito-atlanto axial disease and supraglottic tumor are also a high risk group for difficult intubation ${ }^{36}$. It has been reported that in ENT surgeries, inspite of good glottic view, there is difficulty in insertion of tracheal tube12. In nasal intubation Magill's forcep is used to direct tip of tracheal tube to glottis, and in flexometallic tube stylet is needed to insert the tube and tube sometimes rotate on stylet ${ }^{37}$. These may be the reasons that use of flexometallic tube or nasotracheal intubation had significant association with DI $(\mathrm{P}=0.004)$. Further, resident doctors were not much accustomed of using nasotracheal and flexometallic tubes, which may be the reason of increased incidence of difficult intubation. With experience, these intubations become easy.

Certain airway predictor tests have been deviced to anticipate difficult airways but none of them is $100 \%$ perfect. It has been suggested that combining these tests improves the predictive value 38 .

We observed that all airway tests used in the study (IIG, MMPG, ULBT, TMD, SMD and SLM) had high negative predictive value means they identify easy intubation more precisely as documented by other authors ${ }^{11,14,39}$.

Odd's ratio suggested that ULBT and MMPG are "nearly perfect" airway predictors which can be used for screening of difficult intubation as they had very high sensitivity $(92.8 \%$ and $85.7 \%$ respectively).

Likelihood ratio indicates that presence of ULBT III is the best predictor of difficult intubation and absence of MMPG III and IV is the best single test to rule out difficult intubation. Bhatt et al ${ }^{39}$ examined ULBT and MMPG to predict difficult intubation and reported that a combination of ULBT and MMPG test in parallel is more sensitive, specific and has a higher discriminative power which is clinically relevant than MMPG or ULBT alone. The accuracy of ULBT $(93 \%)$ was much higher than that of MMPG alone (81.6\%). Khan et al14 reported that the specificity and accuracy of the ULBT were significantly higher thanMMPG, TMD, SMD and IIG individually (specificity was $91.69 \%, 82.27 \%, 70.64 \%$ and $82.27 \%$ respectively and accuracy was $91.05 \%, 71.32,81.84$ and $76.58 \%$ respectively). The combination of ULBT and SMD provided the highest sensitivity $(84.2 \%)$.

In contrast, two large metanalysis ${ }^{2,29}$ mentioned that each of the screening test including MMPG, TMD, IIG, Wilson score yielded poor to moderate sensitivity. Most of them used MMPG and none of them used ULBT which involves the assessment of jaw subluxation and presence of buck teeth in a single test which improves its reliability. The classes of ULBT are clearly demarcated and delineated making inter observer variability highly unlikely ${ }^{14}$.

Mallampatti score estimate the size of the tongue relative to the oral cavity, it assesses whether the mouth can be opened adequately to permit intubation. The wide variation in sensitivity and specificity of MMPG in various studies $9,24,25,30,39,40$ may be because of incorrect evaluation of test 
because of interobserver variability ${ }^{41}$. There may be change in class of visualization with phonation which usually occurs involuntarily and poor demarcation between various classes of $\mathrm{MMPG}^{42}$. SLM as a airway predictor was used in few studies ${ }^{10,43}$, so this test needs further evaluation.

IIG (mouth opening) indicates movement of the temporomandibular joint and exposure of the larynx. Many studies 12,14,26,35 indicated that limited mouth opening is strongly associated with difficult intubation as observed by us. If IIG $<3 \mathrm{~cm}$ is taken, then it becomes highly sensitive test $(100 \%)$ for prediction of difficult intubation. ${ }^{10}$

Thyromental distance (TMD) indicates mandibular space which reflects whether displacement of the tongue by the laryngoscope blade will be easy or difficult but its diagnostic value was proved unsatisfactory in our analysis. Cut off points varies from 4.0 to $7.0 \mathrm{~cm}$. One study ${ }^{44}$ with a cut off less than $4 \mathrm{~cm}$ yielded higher diagnostic performance with positive and negative likelihood ratios of 9.4 and 0.03 respectively and suggested to re-evaluate the test threshold. Another source of heterogeneity may be variation in measurement conditions. TMD could have been measured from inside or outside the mentum, so, standardisation is required ${ }^{2}$. SMD can be indicator of head and neck mobility which is an important factor in determining the ease or difficulty of intubation. According to Shiga et $\mathrm{a}^{12}$, among single factors tests, SMD yielded the highest positive likelihood ratio and diagnostic odds ratio with moderate sensitivity and specificity. The negative likelihood ratio was lower than that of any other test suggesting that it is the best single test for ruling out difficult intubation. The cut off point of SMD was consistently 12.5 to $13.5 \mathrm{~cm}$. However, the diagnostic performance remains inconclusive and further investigation is required because so few studies address $\mathrm{SMD}^{9,24,30}$.

There are a few limitations of our study: firstly,we examined airway predictor test as single test. Using them in combination would have been more informative. Secondly, if the study would have been conducted in a specialised population group like in obstetric patients, obese patients, geriatric patients or sex-specific group, the effect of these factors on the study could have been statistically significant. Inspite of above limitations, some definitive conclusions can be drawn.

We conclude that ULBT and MMPG are nearly perfect airway predictors and should be used routinely during the preanesthetic visit for screening of difficult intubation. Presence of ULBT III is the best predictor of difficult intubation and absence of MMPG III and IV is the best single test to rule out the difficult intubation. Abnormal dentition or airway pathology increase the risk of difficult intubation.

In many hospitals of India like ours fibreoptic bronchoscopy, combitubes, difficult intubation kits are not available in every operation theatre. Therefore, identification of potential difficult intubation in preanesthetic visit is necessary, so that an alternative approach to airway can be planned from the beginning of anesthesia, thus hypoxemia associated with difficult intubation can be avoided.

\section{REFERENCES:}

1. American Society of Anesthesiologists Task Force on Management of the Difficult Airway. Practice guidelines for management of the difficult airway: an updated report by the American Society of Anesthesiologists Task Force on Management of the Difficult Airway. Anesthesiology 2003; 98:1269-77. 
2. Shiga T, Wajima Z, Inoue T, Sakamoto A. Predicting difficult intubation in apparently normal patients: a meta-analysis of bedside screening test performance. Anesthesiology 2005; 103: 429-37.

3. Samsoon GLT, Young JRG: Difficult tracheal intubation: A retrospective study. Anaesthesia 1987; 42: 487-490.

4. Cormack RS, Lehane J. Difficult tracheal intubation in obstetrics. Anaesthesia 1984; 39:1105-11

5. Benumof JL. Difficult laryngoscopy: obtaining the best view. Can J Anaesth 1994; 41:361-5.

6. Vasudevan A, Badhe AS. Predictors of difficult intubation - a simple approach. The Internet Journal of Anesthesiology 2009; 20(2). DOI: 10.5580/13aa

7. Mallampati SR, Gatt SP, Gugino LD, Waraksa B, Freiburger D, Liu PL. A clinical sign to predict difficult tracheal intubation: A prospective study. Can Anaesth Soc J 1985; 32:429-434.

8. Patil VU, Stehling LC, Zaunder HL, eds. Fiberoptic Endoscopy in Anesthesia. Chicago, Year Book Medical 1983; 79.

9. Allahyary E, Ghaemei SR , Azemati S. Comparison of six methods for predicting difficult intubation in obstetric patients. Iran Red Crescent Med J 2008; 10: 197-204.

10. Aftab S, Raja D, Rashdi S, Khalid A. Preoperative assessment of risk factors for difficult intubation. Pakistan Journal of Surgery 2008; 24: 60-4.

11. Wilson ME, Spiegelhalter D, Robertson JA, Lesser P. Predicting difficult intubation. Br J Anaesth 1988; 61: 211-6.

12. Arne J, Descoins J, Fusciardi P, Ingrand P, Ferrier B, Boudigues D, et al. Preoperative assessment for difficult intubation in general and ENT surgery: predictive value of a clinical multivariate risk index. Br J Anaesth 1998; 80: 140-6.

13. Descoins P, Arne J, Bresard D, Aries J, Fusciardi J. Proposal for a new multifactor screening score of difficult intubation in ORL and stomatognathic surgery: preliminary study. Ann Fr Anesth Reanim. 1994; 13:195-200.

14. Khan ZH, Kashfi A, Ebrahimkhani E. A comparison of the upper lip bite test (a simple new technique) with modified mallampati classification in predicting difficulty in endotracheal intubation: A prospective blinded study. Anesth Analg 2003; 96:595-9.

15. Hopkins, W. G. (2000). A new view of statistics. Internet Society for Sport Science: http://www.sportsci.org/resource/stats. Accessed on: 19/02/2012

16. King TA, Adams AP. Failed tracheal intubation. Br J Anaesth 1990;65:400-14

17. Benumof JL. Management of the difficult airway: With special emphasis on awake tracheal intubation. Anesthesiology 1991; 75: 1087-110.

18. Biboulet P, Aubas P, Dubourdieu J, Rubenovitch J, Capdevila X, d'Athis F. Fatal and non fatal cardiac arrests related to anaesthesia. Can J Anaesth 2001; 48: 326-32

19. Caplan RA, Posner KL, Ward RJ, Cheney FW. Adverse respiratory events in anesthesia: A closed claims analysis. Anesthesiology 1990; 72:828-33.

20. Cattano D, Panicucci E, Paolicchi A, Forfori F, Giunta F, Hagberg C. Risk factors assessment of difficult airway: An Italian survey of 1956 patients. Anesth Analg 2004; 99:1774-9.

21. Ezri T, Gewurtz G, Sessler DI, B. Medalion, P. Szmuk, C. Hagberg, et al. Prediction of difficult laryngoscopy in obese patients by ultrasound quantification of anterior neck soft tissue. Anaesthesia 2003; 58: 1111-4. 
22. Gercek A, Lim S, Isler FB, Eti Z, Gogus FY. The prediction of difficult intubation with bedside scoring systems. Marmara Med J 2003; 16: 16-9.

23. Naguib M, Scamman FL, Sullivan CO, Aker J, Ross AF, Kosmach S, et al. Predictive performance of three multivariate difficult tracheal intubation models: a double-blind, casecontrolled study. Anesth Analg 2006;102: 818-24

24. Khan ZH, Mohammadi M, Rasouli MR, Farrokhnia F, Khan RH. The diagnostic value of the upper lip bite test combined with sternomental distance, thyromental distance, and interincisor distance for prediction of easy laryngoscopy and intubation: A prospective study. Anesth Analg 2009;109: 822-4

25. Adamus M, Fritscherova S, Hrabalek L, Gabrhelik T, Zapletalova J, Janout V. Mallampati test as a predictor of laryngoscopic view. Biomed Pap Med Fac Univ Palacky Olomouc Czech Repub. 2010; 154: 339-344.

26. Adnet F, Racine SX, Borron SW, Clemessy JL, Fournier JL, Lapostolle F, et al. A survey of tracheal intubation difficulty in the operating room: A prospective observational study. Acta Anaesthesiol Scand 2001;45: 327-32

27. Bouaggad A, Nejmi SE, Bouderka MA, Abbassi O. Prediction of difficult tracheal intubation in thyroid surgery. Anesth Analg 2004; 99:603-6.

28. Juvin P, Lavaut E, Dupont H, Lefevre P, Demetriou M, Dumoulin JL, et al. Difficult tracheal intubation is more common in obese than in lean patients. Anesth Analg 2003; 97: 595-600.

29. Lee A, Fan LTY, Karmakar MK, Kee WDN. A systematic review (meta-analysis) of the accuracy of the mallampati tests to predict the difficult airway. Anesth Analg 2006;102:1867-78

30. Domi. Predicting difficult intubation. Maced J Med Sci. $2009 ; 2: 141-44$

31. Lavi R, Segal D, Ziser A. Predicting difficult airways using the intubation difficult scale: A study comparing obese and non-obese patients. J Clin Anesth 2009; 21: 264-267.

32. Adams JP, Murphy PG. Obesity in anaesthesia and intensive care. Br J Anaesth 2000; 85: 91108.

33. Türkan S, Ates Y, Cuhruk H, Tekdemir I. Should we re-evaluate the variables for predicting the difficult airway in anesthesiology? Anesth Analg 2002; 94: 1340-4.

34. Angelini G, Ketzler JT, Coursin DB. Use of propofol and other non benzodiazepine sedatives in the intensive care unit. Crit Care Clin 2001; 863-80

35. Eberhart LH, Arndt C, Aust HJ, Kranke P, Zoremba M, Morin A. A simplified risk score to predict difficult intubation: development and prospective evaluation in 3763 patients. Eur J Anaesthesiol 2010; 27: 935-40

36. Koay CK. Difficult tracheal intubation-analysis and management in 37 cases. Singapore Med J 1998; 39: 112-4.

37. Calder I, CaladerJ, Crockard HA. Difficult direct laryngoscopy in patient with cervical spine disease. Anaesthesia 1995;50:756-763.

38. Dorsch JA, Dorsch SE. In: Understanding Anaesthesia equipment $5^{\text {th }}$ edition. Lippincott Williams \& Wilkins, United States of America 2008; pp 566-567.

39. Bhatt RR, Mishra SK, Badhe AS. Comparison of upper lip bite test and modified mallampati classification in predicting difficult intubation. The Internet Journal of Anesthesiology ISSN: 1092-406X 2007; 13(1).

40. Gupta AK, Ommid M, Nengroo S, Naqash I, Mehta A. Predictors of difficult intubation: Study in Kashmiri population. Pravara Med Rev 2009; 4: 12-16. 
41. Leopold H.J, Eberhart, Christian Arndt. The reliability and validity of the upper lip bite test compared with the Mallampati classification to predict difficult laryngoscopy: An external prospective evaluation. Anesth Analg 2005; 101:284-9.

42. Chohedri AH, Allahari E, Tabari M. The upper lip bite test: Prediction of difficult endotracheal intubation. Professional Med J 2005; 12: 440-445.

43. Savva D. Prediction of difficult tracheal intubation. Br J Anaesth 1994; 73: 109-153.

44. Ayoub C, Baraka A, el- Khatib M, Muallem M, Kawkabani N, Soueide A. A new cut off point of Thyromental distance for prediction of difficult airway. Middle East J Anesthesiol 2000; 46:75-79

Table No. 1: Association of Mean Age, Weight and Sex with Difficulty in Laryngoscopy and Intubation

\begin{tabular}{|c|c|c|c|c|c|c|c|c|}
\hline & & $\begin{array}{c}\text { Total } \\
n=435\end{array}$ & $\begin{array}{c}\text { EVL } \\
\text { (CL I,II) } \\
n=380\end{array}$ & $\begin{array}{c}\text { DVL } \\
\text { (CL III,IV) } \\
n=55\end{array}$ & \begin{tabular}{|c|}
$\mathbf{P}$ \\
Valu \\
$\mathbf{e}$
\end{tabular} & $\begin{array}{c}E I \\
(D I S \leq 4) \\
n=393\end{array}$ & $\begin{array}{c}\text { DI } \\
(D I S>4) \\
n=42\end{array}$ & $\begin{array}{c}\text { P } \\
\text { Valu } \\
\mathbf{e}\end{array}$ \\
\hline \multirow{5}{*}{$\begin{array}{l}\text { Age } \\
\text { group } \\
\text { (yrs) }\end{array}$} & $18-35$ & $\begin{array}{c}226 \\
(52.00 \%)\end{array}$ & $\begin{array}{c}208 \\
(92.03 \%)\end{array}$ & $\begin{array}{c}18 \\
(7.96 \%)\end{array}$ & & $\begin{array}{c}212 \\
(93.80 \%)\end{array}$ & $\begin{array}{c}14 \\
(6.19 \%)\end{array}$ & \\
\hline & $36-50$ & $\begin{array}{c}124 \\
(28.50 \%)\end{array}$ & $\begin{array}{c}106 \\
(85.5 \%)\end{array}$ & $\begin{array}{c}18 \\
(14.5 \%)\end{array}$ & & $\begin{array}{c}109 \\
(87.90 \%)\end{array}$ & $\begin{array}{c}15 \\
(12.30 \%)\end{array}$ & \\
\hline & $51-65$ & $\begin{array}{c}57 \\
(13.10 \%) \\
\end{array}$ & $\begin{array}{c}43 \\
(75.43 \%) \\
\end{array}$ & $\begin{array}{c}14 \\
(24.56 \%) \\
\end{array}$ & & $\begin{array}{c}48 \\
(84.20 \%)\end{array}$ & $\begin{array}{c}9 \\
(15.80 \%)\end{array}$ & \\
\hline & $>65$ & $\begin{array}{c}28 \\
(6.40 \%) \\
\end{array}$ & $\begin{array}{c}23 \\
(82.20 \%) \\
\end{array}$ & $\begin{array}{c}5 \\
(17.90 \%) \\
\end{array}$ & & $\begin{array}{c}24 \\
(85.70 \%) \\
\end{array}$ & $\begin{array}{c}4 \\
(14.30 \%) \\
\end{array}$ & \\
\hline & $\begin{array}{c}\text { Mean } \pm S \\
\text { D }\end{array}$ & $\begin{array}{c}38.03+15.1 \\
9\end{array}$ & $37.53 \pm 15.25$ & $\begin{array}{c}41.30 \pm 14.9 \\
3\end{array}$ & $\begin{array}{c}0.551 \\
(\mathrm{NS})\end{array}$ & $\begin{array}{c}37.63 \pm 15.2 \\
7\end{array}$ & $\begin{array}{c}41.74 \pm 14.0 \\
3\end{array}$ & $\begin{array}{l}0.53 \\
\text { (NS) }\end{array}$ \\
\hline \multirow{6}{*}{$\begin{array}{l}\text { Weigh } \\
\text { t (kg) }\end{array}$} & $30-45$ & $\begin{array}{c}25 \\
(5.75 \%)\end{array}$ & $\begin{array}{c}24 \\
(96 \%)\end{array}$ & $\begin{array}{c}1 \\
(1.82 \%)\end{array}$ & & $\begin{array}{c}25 \\
(100 \%)\end{array}$ & $\begin{array}{c}0 \\
(0.00 \%)\end{array}$ & \\
\hline & $46-60$ & $\begin{array}{c}240 \\
(55.17 \%) \\
\end{array}$ & $\begin{array}{c}213 \\
(88.8 \%) \\
\end{array}$ & $\begin{array}{c}27 \\
(49.09 \%) \\
\end{array}$ & & $\begin{array}{c}218 \\
(90.8 \%) \\
\end{array}$ & $\begin{array}{c}22 \\
(9.2 \%) \\
\end{array}$ & \\
\hline & $61-75$ & $\begin{array}{c}108 \\
(24.83 \%)\end{array}$ & $\begin{array}{c}93 \\
(86.3 \%)\end{array}$ & $\begin{array}{c}15 \\
(13.9 \%)\end{array}$ & & $\begin{array}{c}96 \\
(88.8 \%)\end{array}$ & $\begin{array}{c}12 \\
(11.2 \%)\end{array}$ & \\
\hline & $75-90$ & $\begin{array}{c}52 \\
(12.0 \%)\end{array}$ & $\begin{array}{c}43 \\
(82.7 \%)\end{array}$ & $\begin{array}{c}9 \\
(17.3 \%)\end{array}$ & & $\begin{array}{c}46 \\
(88.46 \%)\end{array}$ & $\begin{array}{c}6 \\
(11.54 \%)\end{array}$ & \\
\hline & $>90$ & $\begin{array}{c}10 \\
(2.3 \%) \\
\end{array}$ & $\begin{array}{c}7 \\
(70.0 \%) \\
\end{array}$ & $\begin{array}{c}3 \\
(30.0 \%) \\
\end{array}$ & & $\begin{array}{c}8 \\
(80 \%) \\
\end{array}$ & $\begin{array}{c}2 \\
(20 \%) \\
\end{array}$ & \\
\hline & Mean \pm SD & $56.80 \pm 7.97$ & $\begin{array}{c}56.1821 \pm 7.30 \\
0 \\
\end{array}$ & $\begin{array}{c}60.929 \pm \\
1.069 \\
\end{array}$ & $\begin{array}{c}0.610 \\
(\mathrm{NS}) \\
\end{array}$ & $56.20 \pm 7.42$ & $\begin{array}{c}62.42 \pm \\
1.049 \\
\end{array}$ & $\begin{array}{l}0.59 \\
(\mathrm{NS}) \\
\end{array}$ \\
\hline \multirow{2}{*}{ Sex } & $\begin{array}{l}\text { Male } \\
\mathrm{n}(\%)\end{array}$ & $\begin{array}{c}202 \\
(46.5 \%)\end{array}$ & $\begin{array}{c}172 \\
(85.14 \%)\end{array}$ & $\begin{array}{c}30 \\
(4.86 \%)\end{array}$ & \multirow{2}{*}{$\begin{array}{r}0.197 \\
(\mathrm{NS})\end{array}$} & $\begin{array}{c}179 \\
(88.6 \%)\end{array}$ & $23(11.4 \%)$ & \multirow{2}{*}{$\begin{array}{l}0.255 \\
\text { (NS) }\end{array}$} \\
\hline & $\begin{array}{c}\text { Female } \\
\mathrm{n}(\%)\end{array}$ & $\begin{array}{c}233 \\
(53.5 \%)\end{array}$ & $\begin{array}{c}208 \\
(89.27 \%)\end{array}$ & $\begin{array}{c}25 \\
(1.07 \%)\end{array}$ & & $\begin{array}{c}214 \\
(91.8 \%)\end{array}$ & $19(8.2 \%)$ & \\
\hline
\end{tabular}

NS= Not significant, EVL = Easy visualization of larynx, DVL = Difficult visualization of larynx, EI $=$ Easy intubation, DI = Difficult intubation, DIS = Difficult Intubation Score 
Table No. 2: Relationship Between laryngoscopic grade and number of intubation attempts and requirement of OELM.

\begin{tabular}{|c|c|c|c|c|c|c|c|c|c|c|c|c|}
\hline \multirow{2}{*}{\multicolumn{2}{|c|}{$\begin{array}{l}\text { Laryngosco } \\
\text { pic grade } \\
\text { (Cormack \& } \\
\text { Lehane) }\end{array}$}} & \multirow[b]{2}{*}{$\begin{array}{c}\text { Total } \\
\mathrm{n}=435\end{array}$} & \multicolumn{3}{|c|}{$\begin{array}{l}\text { Difficulty during } \\
\text { intubation }\end{array}$} & \multicolumn{4}{|c|}{ No. of Attempts } & \multicolumn{3}{|c|}{$\begin{array}{c}\text { Optimum External } \\
\text { Laryngeal Pressure } \\
\text { (OELM) }\end{array}$} \\
\hline & & & $\begin{array}{c}\text { EI } \\
(\mathrm{DIS} \\
<4) \\
\mathrm{n}=393\end{array}$ & $\begin{array}{c}\mathrm{DI} \\
(\mathrm{DIS} \geq 4 \\
\mathrm{n}=42\end{array}$ & $\begin{array}{c}\mathrm{P} \\
\text { valu } \\
\mathrm{e}\end{array}$ & $\begin{array}{c}1 \\
n=378\end{array}$ & $\begin{array}{c}2 \\
n=52\end{array}$ & $\begin{array}{c}3 \\
n=5\end{array}$ & $\begin{array}{c}P \\
\text { value }\end{array}$ & $\begin{array}{c}\begin{array}{c}\text { Requir } \\
\text { ed }\end{array} \\
n=130\end{array}$ & \begin{tabular}{|c|} 
Not \\
require \\
$\mathrm{d}$ \\
$\mathrm{n}=305$
\end{tabular} & $\begin{array}{c}\mathrm{P} \\
\text { value }\end{array}$ \\
\hline $\begin{array}{c}\text { EVL } \\
(\mathrm{I}, \mathrm{II}) \\
\mathrm{n}=380\end{array}$ & I & $\begin{array}{c}273 \\
(62.76 \\
\%) \\
\end{array}$ & $\begin{array}{c}273 \\
(100 \%)\end{array}$ & $\begin{array}{c}0 \\
(0.00 \\
\%) \\
\end{array}$ & \multirow{2}{*}{$\begin{array}{c}0.00 \\
0 \\
\mathbf{S}\end{array}$} & $\begin{array}{c}264 \\
(96.7 \\
\%) \\
\end{array}$ & $\begin{array}{c}9 \\
(3.3 \%)\end{array}$ & $\begin{array}{c}0 \\
(0.00 \\
\%) \\
\end{array}$ & \multirow{4}{*}{$\begin{array}{c}<0.00 \\
1 \\
\mathrm{HS}\end{array}$} & $\begin{array}{c}40 \\
(14.6 \% \\
\quad) \\
\end{array}$ & $\begin{array}{c}233 \\
(85.3 \\
\%) \\
\end{array}$ & \multirow{4}{*}{$\begin{array}{c}<0.00 \\
1 \\
\text { HS }\end{array}$} \\
\hline $\begin{array}{c}(87.35 \\
\%)\end{array}$ & II & $\begin{array}{c}107 \\
(24.60 \\
\%)\end{array}$ & $\begin{array}{c}105 \\
(98.13 \\
\%)\end{array}$ & $\begin{array}{c}2 \\
(1.86 \\
\%)\end{array}$ & & $\begin{array}{c}99 \\
(92.5 \\
\%)\end{array}$ & $\begin{array}{c}7 \\
(6.5 \%)\end{array}$ & $\begin{array}{c}1 \\
(0.9 \%)\end{array}$ & & $\begin{array}{c}35 \\
(32.7 \% \\
)\end{array}$ & \begin{tabular}{|c|}
68 \\
$67.3 \%$ \\
)
\end{tabular} & \\
\hline \multirow{2}{*}{$\begin{array}{c}\text { DVL } \\
\text { (III, IV) } \\
\mathrm{n}=55 \\
(12.65 \\
\%)\end{array}$} & III & $\begin{array}{c}53 \\
(12.18 \\
\%)\end{array}$ & $\begin{array}{c}15 \\
(28.3 \% \\
)\end{array}$ & $\begin{array}{c}38 \\
(71.7 \\
\%)\end{array}$ & \multirow{2}{*}{$\begin{array}{c}0.46 \\
\text { NS }\end{array}$} & $\begin{array}{c}15 \\
(28.3 \\
\%)\end{array}$ & $\begin{array}{c}36 \\
(67.9 \\
\%)\end{array}$ & $\begin{array}{c}2 \\
(3.8 \%)\end{array}$ & & $\begin{array}{c}53 \\
(100 \%)\end{array}$ & \begin{tabular}{|c|}
0 \\
$0.00 \%$ \\
)
\end{tabular} & \\
\hline & IV & $\begin{array}{c}2 \\
(0.46 \% \\
\quad)\end{array}$ & $\begin{array}{c}0 \\
(0.00 \% \\
\quad)\end{array}$ & \begin{tabular}{|c|}
2 \\
$(100 \%$ \\
)
\end{tabular} & & $\begin{array}{c}0 \\
(0.00 \\
\%)\end{array}$ & $\begin{array}{c}0 \\
(0.00 \\
\%)\end{array}$ & \begin{tabular}{|c|}
2 \\
$(100 \%$ \\
)
\end{tabular} & & $\begin{array}{c}2 \\
(100 \%)\end{array}$ & $\begin{array}{c}0 \\
0.00 \% \\
)\end{array}$ & \\
\hline
\end{tabular}

$\mathrm{EVL}=$ Easy visualization of larynx, DVL = Difficult visualization of larynx, EI = Easy intubation, DI = Difficult intubation, DIS = Difficult Intubation Score, $\mathrm{S}=$ significant, NS= not significant, HS= highly significant 
Table No. 3: Relationship Between Dentition, Airway Pathology, and Types of Endotracheal tube with laryngoscopic grade and intubation

\begin{tabular}{|c|c|c|c|c|c|c|c|c|c|}
\hline & & & $\begin{array}{c}\text { Total } \\
\mathrm{n}=435\end{array}$ & $\begin{array}{c}\mathrm{EVL} \\
\mathrm{n}=380\end{array}$ & $\begin{array}{c}\text { DVL } \\
\mathrm{n}=55\end{array}$ & $\begin{array}{c}\mathrm{P} \\
\text { Value }\end{array}$ & $\begin{array}{c}E I \\
n=393\end{array}$ & $\begin{array}{c}\text { DI } \\
n=42\end{array}$ & $\begin{array}{c}\mathrm{P} \\
\text { Value }\end{array}$ \\
\hline \multirow[t]{3}{*}{ Dentition } & \multirow{2}{*}{\multicolumn{2}{|c|}{ Normal teeth }} & 385 & 343 & 42 & \multirow{3}{*}{$\begin{array}{c}0.003 \\
\mathrm{~S}\end{array}$} & 355 & 30 & \multirow{3}{*}{$\begin{array}{c}<0.00 \\
1\end{array}$} \\
\hline & & & & ) & & & & & \\
\hline & \multicolumn{2}{|c|}{$\begin{array}{c}\text { Bucked / } \\
\text { Missing teeth }\end{array}$} & $\begin{array}{c}50 \\
(11.50 \%)\end{array}$ & $\begin{array}{c}37 \\
(74.00 \% \\
)\end{array}$ & $\begin{array}{c}13 \\
(26.00 \%)\end{array}$ & & $\begin{array}{c}38 \\
(76.0 \%)\end{array}$ & $\begin{array}{c}12 \\
(24.0 \%)\end{array}$ & \\
\hline \multirow{8}{*}{$\begin{array}{c}\text { Presence of } \\
\text { airway } \\
\text { pathology }\end{array}$} & \multirow{2}{*}{\multicolumn{2}{|c|}{ Absent }} & 413 & 374 & 39 & \multirow{8}{*}{$\begin{array}{l}0.00 \\
0 \\
S\end{array}$} & & & \multirow{8}{*}{$\begin{array}{l}0.000 \\
S\end{array}$} \\
\hline & & & $(94.94 \%)$ & ) & (9.44\%) & & $(93.0 \%)$ & $(7.0 \%)$ & \\
\hline & \multicolumn{2}{|r|}{ Present } & 22 & 6 & 16 & & 9 & 13 & \\
\hline & \multirow{5}{*}{ 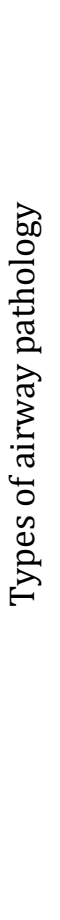 } & $\begin{array}{l}\text { Ludwig } \\
\text { Angina }\end{array}$ & $\begin{array}{c}4 \\
(18.18 \%)\end{array}$ & $\begin{array}{c}0 \\
(0.00 \%)\end{array}$ & $\begin{array}{c}4 \\
(100 \%)\end{array}$ & & $\begin{array}{c}1 \\
(25 \%)\end{array}$ & $\begin{array}{c}3 \\
(75 \%)\end{array}$ & \\
\hline & & $\begin{array}{c}\# \\
\text { Mandible }\end{array}$ & $\begin{array}{c}7 \\
(31.82 \%)\end{array}$ & $\begin{array}{c}2 \\
(14.20 \% \\
)\end{array}$ & $\begin{array}{c}5 \\
(71.00 \%)\end{array}$ & & $\begin{array}{c}3 \\
(42.30 \% \\
)\end{array}$ & $\begin{array}{c}4 \\
(87.70 \% \\
)\end{array}$ & \\
\hline & & $\begin{array}{l}\text { Large } \\
\text { thyroid } \\
\text { Goiter }\end{array}$ & $\begin{array}{c}6 \\
(27.27 \%)\end{array}$ & $\begin{array}{c}2 \\
(33.33 \% \\
)\end{array}$ & $\begin{array}{c}4 \\
(66.60 \%)\end{array}$ & & $\begin{array}{c}3 \\
(50.00 \% \\
)\end{array}$ & $\begin{array}{c}3 \\
(50.00 \% \\
)\end{array}$ & \\
\hline & & $\begin{array}{c}\text { With } \\
\text { cervical } \\
\text { Collar }\end{array}$ & $\begin{array}{c}2 \\
(9.09 \%)\end{array}$ & $\begin{array}{c}1 \\
(50.00 \% \\
)\end{array}$ & $\begin{array}{c}1 \\
(50.00 \%)\end{array}$ & & $\begin{array}{c}1 \\
(50.00 \% \\
)\end{array}$ & $\begin{array}{c}1 \\
(50.00 \% \\
)\end{array}$ & \\
\hline & & $\begin{array}{c}\text { Burn with } \\
\text { neck } \\
\text { Contractur } \\
\text { e }\end{array}$ & $\begin{array}{c}3 \\
(13.64 \%)\end{array}$ & $\begin{array}{c}1 \\
(33.33 \% \\
)\end{array}$ & $\begin{array}{c}2 \\
(66.66 \%)\end{array}$ & & $\begin{array}{c}1 \\
(33.33 \% \\
)\end{array}$ & $\begin{array}{c}2 \\
(66.66 \% \\
)\end{array}$ & \\
\hline & & Oral & $\begin{array}{c}379 \\
(87.13 \% \\
)\end{array}$ & & & & $\begin{array}{c}347 \\
(91.5 \% \\
)\end{array}$ & $\begin{array}{c}32 \\
(8.5 \%)\end{array}$ & \\
\hline $\begin{array}{c}\text { Type of } \\
\text { Endotrachea }\end{array}$ & & Nasal & $\begin{array}{c}32 \\
(7.35 \%)\end{array}$ & & $\begin{array}{c}\text { Not } \\
\text { applicabl }\end{array}$ & & $\begin{array}{c}26 \\
(81.2 \%\end{array}$ & $\begin{array}{c}6 \\
(18.8 \%\end{array}$ & 0.004 \\
\hline & & xometallic & $\begin{array}{c}24 \\
(5.52 \%)\end{array}$ & & & & $\begin{array}{c}20 \\
(83.3 \% \\
)\end{array}$ & $\begin{array}{c}4 \\
(16.7 \% \\
)\end{array}$ & \\
\hline
\end{tabular}


EVL = Easy visualization of larynx, DVL = Difficult visualization of larynx, EI = Easy intubation, DI = Difficult intubation, $\mathrm{S}=$ significant

Table No. 4: Relationship between laryngoscopic grade and intubation with Various Airway Predictors

\begin{tabular}{|c|c|c|c|c|c|c|c|c|}
\hline $\begin{array}{l}\text { Airway } \\
\text { Predictors }\end{array}$ & Interpretation & $\begin{array}{l}\text { Total } \\
n=435\end{array}$ & $\begin{array}{c}\text { EVL } \\
\text { CL I,II } \\
n=380\end{array}$ & $\begin{array}{c}\text { DVL } \\
\text { CL III, IV } \\
n=55\end{array}$ & $\begin{array}{c}\mathrm{P} \\
\text { Value }\end{array}$ & $\begin{array}{c}E I \\
D I S \leq 4 \\
n=393\end{array}$ & $\begin{array}{c}\text { DI } \\
\text { DIS }>4 \\
n=42\end{array}$ & $\begin{array}{c}\mathrm{P} \\
\text { Value }\end{array}$ \\
\hline \multirow[t]{2}{*}{$\begin{array}{l}\text { Interincisor } \\
\text { gap (IIG) }\end{array}$} & $\begin{array}{l}\text { Predicts } \\
\text { difficult } \\
(\mathrm{IIG}<4 \mathrm{~cm})\end{array}$ & $\begin{array}{c}58 \\
(13.3 \%)\end{array}$ & $\begin{array}{c}23 \\
(39.7 \%)\end{array}$ & $\begin{array}{c}35 \\
(60.3 \%)\end{array}$ & \multirow{2}{*}{$\begin{array}{c}<0.001 \\
\mathrm{~S}\end{array}$} & $\begin{array}{c}36 \\
(61.10 \%)\end{array}$ & $\begin{array}{c}22 \\
(37.90 \%)\end{array}$ & \multirow{2}{*}{$\begin{array}{c}<0.001 \\
\mathrm{~S}\end{array}$} \\
\hline & $\begin{array}{l}\text { Predicts easy } \\
(\mathrm{IIG} \geq 4 \mathrm{~cm})\end{array}$ & $\begin{array}{c}377 \\
(86.7 \%)\end{array}$ & $\begin{array}{c}357 \\
(94.7 \%)\end{array}$ & $\begin{array}{c}20 \\
(5.3 \%)\end{array}$ & & $\begin{array}{c}357 \\
(94.70 \%)\end{array}$ & $\begin{array}{c}20 \\
(5.30 \%)\end{array}$ & \\
\hline \multirow[t]{2}{*}{$\begin{array}{l}\text { Upper lip bite } \\
\text { test (ULBT) }\end{array}$} & $\begin{array}{l}\text { Predicts } \\
\text { difficult } \\
\text { (ULBT Class } \\
\text { III) }\end{array}$ & $\begin{array}{c}69 \\
(15.86 \%)\end{array}$ & $\begin{array}{c}26 \\
(37.68 \%)\end{array}$ & $\begin{array}{c}43 \\
(62.32 \%)\end{array}$ & \multirow{2}{*}{$\begin{array}{c}<0.001 \\
\mathrm{~S}\end{array}$} & $\begin{array}{c}33 \\
(47.83 \%)\end{array}$ & $\begin{array}{c}36 \\
(52.17 \%)\end{array}$ & \multirow{2}{*}{$\begin{array}{c}<0.001 \\
S\end{array}$} \\
\hline & $\begin{array}{l}\text { Predict easy } \\
\text { (ULBT class I } \\
\& \text { II }\end{array}$ & $\begin{array}{c}366 \\
(84.14 \%)\end{array}$ & $\begin{array}{c}354 \\
(96.72 \%)\end{array}$ & $\begin{array}{c}12 \\
(3.28 \%)\end{array}$ & & $\begin{array}{c}360 \\
(98.36 \%)\end{array}$ & $\begin{array}{c}6 \\
(1.64 \%)\end{array}$ & \\
\hline \multirow[t]{2}{*}{$\begin{array}{l}\text { Modified } \\
\text { Mallampatti } \\
\text { grading } \\
\text { (MMPG) }\end{array}$} & \begin{tabular}{|l} 
Predicts \\
difficult \\
(MMPG Class \\
III, IV)
\end{tabular} & $\begin{array}{c}91 \\
(20.92 \%)\end{array}$ & $\begin{array}{c}53 \\
(58.24 \%)\end{array}$ & $\begin{array}{c}38 \\
(41.76 \%)\end{array}$ & \multirow{2}{*}{$\begin{array}{c}0.000 \\
S\end{array}$} & $\begin{array}{c}52 \\
(57.14 \%)\end{array}$ & $\left|\begin{array}{c}39 \\
(42.86 \%)\end{array}\right|$ & \multirow{2}{*}{$\begin{array}{c}0.000 \\
S\end{array}$} \\
\hline & $\begin{array}{l}\text { Predict easy } \\
\text { (MMPG class I } \\
\& \text { II) }\end{array}$ & $\begin{array}{c}344 \\
(79.08 \%)\end{array}$ & $\begin{array}{c}327 \\
(95.06 \%)\end{array}$ & $\begin{array}{c}17 \\
(4.94 \%)\end{array}$ & & $\begin{array}{c}341 \\
(99.13 \%)\end{array}$ & $\begin{array}{c}3 \\
(0.87 \%)\end{array}$ & \\
\hline \multirow[t]{2}{*}{$\begin{array}{l}\text { Subluxation of } \\
\text { Mandible } \\
\text { (SLM) }\end{array}$} & $\begin{array}{l}\text { Predicts } \\
\text { difficult } \\
\text { (SLM Class III) }\end{array}$ & $\begin{array}{c}72 \\
(16.55 \%)\end{array}$ & $\begin{array}{c}40 \\
(55.56 \%)\end{array}$ & $\begin{array}{c}32 \\
(44.44 \%)\end{array}$ & \multirow{2}{*}{$\begin{array}{c}0.000 \\
S\end{array}$} & $\begin{array}{c}43 \\
(59.72 \%)\end{array}$ & $\left|\begin{array}{c}29 \\
(40.28 \%)\end{array}\right|$ & \multirow{2}{*}{$\begin{array}{c}0.000 \\
\mathrm{~S}\end{array}$} \\
\hline & $\begin{array}{l}\text { Predict easy } \\
\text { (SLM class I \& } \\
\text { II) }\end{array}$ & $\begin{array}{c}363 \\
(83.45 \%)\end{array}$ & $\begin{array}{c}340 \\
(93.66 \%)\end{array}$ & $\begin{array}{c}23 \\
(6.34 \%)\end{array}$ & & $\begin{array}{c}350 \\
(96.42 \%)\end{array}$ & $\begin{array}{c}13 \\
(3.58 \%)\end{array}$ & \\
\hline \multirow[t]{2}{*}{$\begin{array}{c}\text { Thyromental } \\
\text { Distance } \\
\text { (TMD) }\end{array}$} & $\begin{array}{l}\text { Predicts } \\
\text { difficult } \\
(\text { TDM }<6.5 \mathrm{~cm})\end{array}$ & $\begin{array}{c}94 \\
(21.61 \%)\end{array}$ & $\begin{array}{c}71 \\
(75.53 \%)\end{array}$ & $\begin{array}{c}23 \\
(24.47 \%)\end{array}$ & \multirow{2}{*}{$\begin{array}{c}0.000 \\
S\end{array}$} & $\begin{array}{c}80 \\
(85.11 \%)\end{array}$ & $\begin{array}{c}14 \\
(14.89 \%)\end{array}$ & \multirow{2}{*}{$\begin{array}{c}0.049 \\
S\end{array}$} \\
\hline & $\begin{array}{l}\text { Predict easy } \\
(\mathrm{TMD} \geq 6.5 \mathrm{~cm})\end{array}$ & $\begin{array}{c}341 \\
(78.39 \%)\end{array}$ & $\begin{array}{c}309 \\
(90.62 \%)\end{array}$ & $\begin{array}{c}32 \\
(9.38 \%)\end{array}$ & & $\begin{array}{c}313 \\
(91.79 \%)\end{array}$ & $\begin{array}{c}28 \\
(8.21 \%)\end{array}$ & \\
\hline $\begin{array}{c}\text { Sternomental } \\
\text { Distance } \\
\text { (SMD) }\end{array}$ & $\begin{array}{l}\text { Predicts } \\
\text { difficult } \\
\text { (SMD } \\
<13.5 \mathrm{~cm})\end{array}$ & $\begin{array}{c}42 \\
(9.66 \%)\end{array}$ & $\begin{array}{c}35 \\
(83.33 \%)\end{array}$ & $\begin{array}{c}7 \\
(16.67 \%)\end{array}$ & $\begin{array}{c}0.409 \\
\text { NS }\end{array}$ & $\begin{array}{c}37 \\
(88.10 \%)\end{array}$ & $\begin{array}{c}5 \\
(11.90 \%)\end{array}$ & $\begin{array}{c}0.409 \\
\text { NS }\end{array}$ \\
\hline
\end{tabular}




\begin{tabular}{|l|l|c|c|c|c|c|c|c|}
\hline \hline & $\begin{array}{l}\text { Predict easy } \\
\text { (SMD } \geq \\
13.5 \mathrm{~cm})\end{array}$ & 393 & 345 & 48 & & 356 & 37 \\
$(90.59 \%)$ & $(9.41 \%)$ & \\
$(87.79 \%)$ & $(12.21 \%)$ & & & & \\
\hline
\end{tabular}

EVL = Easy visualization of larynx, DVL = Difficult visualization of larynx, EI = Easy intubation, $\mathrm{DI}=$ Difficult intubation, $\mathrm{S}=$ significant, $\mathrm{NS}=$ Not significant

Table No. 5: Comparison of sensitivity, specificity, positive and negative predictive value, positive and negative likelihood ratio and odd's ratio of six airway tests for predicting difficult intubation

\begin{tabular}{|c|c|c|c|c|c|c|c|c|}
\hline \multirow[b]{2}{*}{ Test } & \multicolumn{8}{|c|}{ Difficult Intubation } \\
\hline & Sensitivity & Specificity & $\begin{array}{c}\text { Positive } \\
\text { Predictive } \\
\text { value }\end{array}$ & $\begin{array}{c}\text { Negative } \\
\text { Predictive } \\
\text { Value } \\
\end{array}$ & $\begin{array}{c}\text { Positive } \\
\text { Likelihood } \\
\text { Ratio } \\
\end{array}$ & $\begin{array}{c}\text { Negative } \\
\text { Likelihood } \\
\text { Ratio }\end{array}$ & $\begin{array}{l}\text { Odds } \\
\text { Ratio }\end{array}$ & $\begin{array}{c}\text { Confidence } \\
\text { Interval } \\
(95 \% \mathrm{CI}) \\
\end{array}$ \\
\hline $\begin{array}{l}\text { IIG } \\
(<4 \mathrm{~cm})\end{array}$ & $50 \%$ & $90.8 \%$ & $37.3 \%$ & $94.7 \%$ & 5.43 & 0.55 & 10.9 & $\begin{array}{l}5.43- \\
21.87\end{array}$ \\
\hline $\begin{array}{l}\text { ULBT } \\
\text { (Class III) }\end{array}$ & $85.7 \%$ & $96.18 \%$ & $92.3 \%$ & $98.3 \%$ & 21.97 & 0.148 & 65.45 & $\begin{array}{c}25.69- \\
166.7\end{array}$ \\
\hline $\begin{array}{l}\text { MMPG } \\
\text { (Class III } \\
\& \text { IV) }\end{array}$ & $92.8 \%$ & $78.8 \%$ & $42.8 \%$ & $96.7 \%$ & 4.37 & 0.091 & 85.25 & $\begin{array}{l}25.42- \\
285.89\end{array}$ \\
\hline $\begin{array}{l}\text { SLM } \\
\text { (Class III) }\end{array}$ & $69.4 \%$ & $89.05 \%$ & $40.2 \%$ & $96.4 \%$ & 6.3 & 0.34 & 18.15 & $\begin{array}{l}8.78- \\
37.55\end{array}$ \\
\hline $\begin{array}{l}\text { TMD } \\
(<6.5 \mathrm{~cm})\end{array}$ & $33.33 \%$ & $83.9 \%$ & $14.89 \%$ & $91.7 \%$ & 2.06 & 0.79 & 1.95 & $\begin{array}{l}0.98- \\
3.884\end{array}$ \\
\hline $\begin{array}{l}\text { SMD } \\
(<13.5 \mathrm{~cm})\end{array}$ & $11.5 \%$ & $90.5 \%$ & $11.5 \%$ & $90.5 \%$ & 1.21 & 0.97 & 1.30 & $0.4815-$ \\
\hline
\end{tabular}

IIG= Inter Incisor Gap, MMPG= Modified Mallampatti Grading, ULBT= Upper lip bite test, TMD= Thyromental distance, SMD= Sternomental distance, SLM= Subluxation of mandible 
Figure 1: Comparison of sensitivity, specificity, positive and negative predictive value of various airway predictors for difficult intubation and their interpretation using complete scale of Hopkins

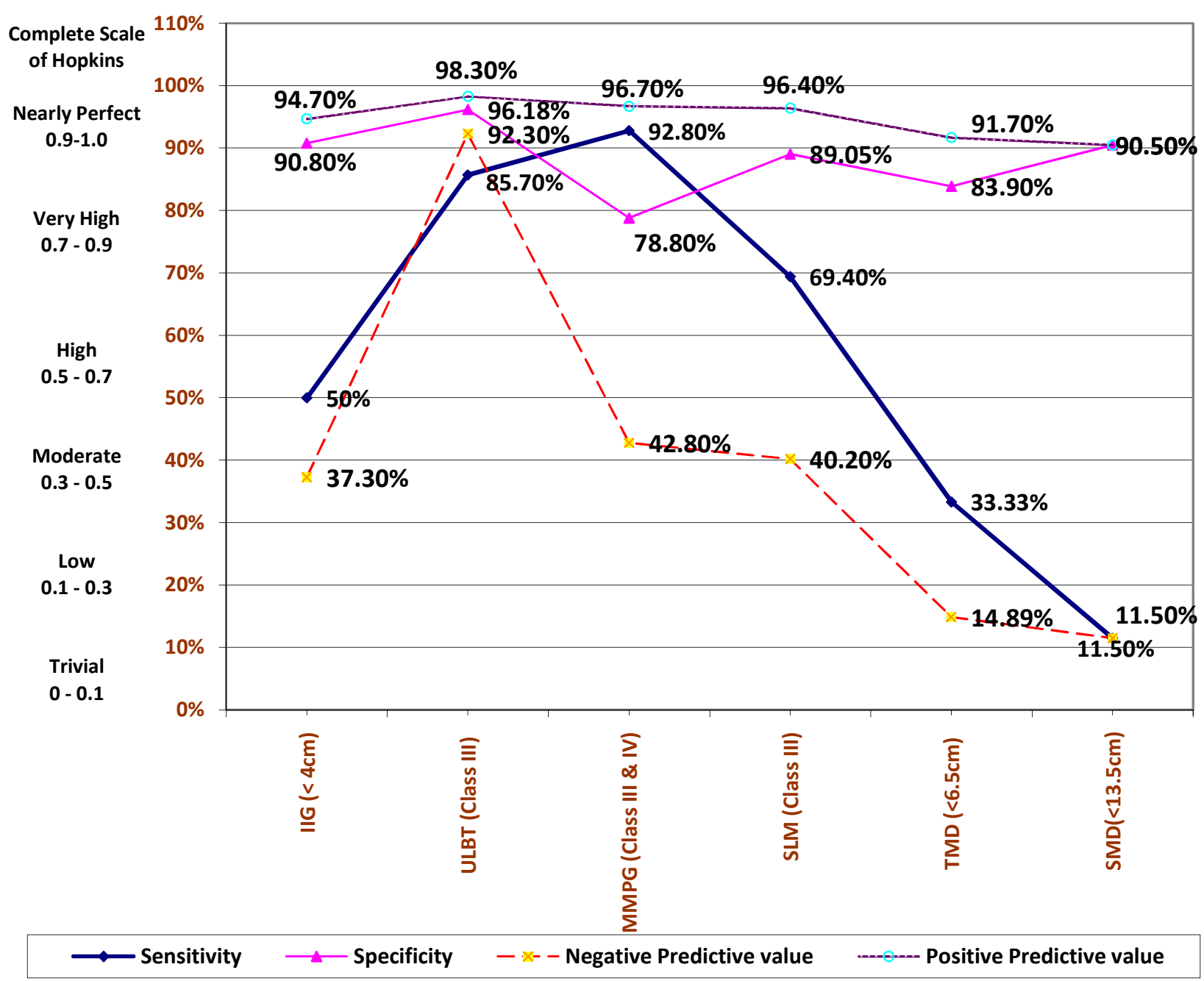

IIG= Inter Incisor Gap, MMPG= Modified Mallampatti Grading, ULBT= Upper lip bite test, TMD= Thyromental distance, $S M D=$ Sternomental distance, SLM= Subluxation of mandible 
Figure 2: Comparison of Odds ratio of various airway predictors for difficult intubation and their interpretation using complete scale of Hopkins

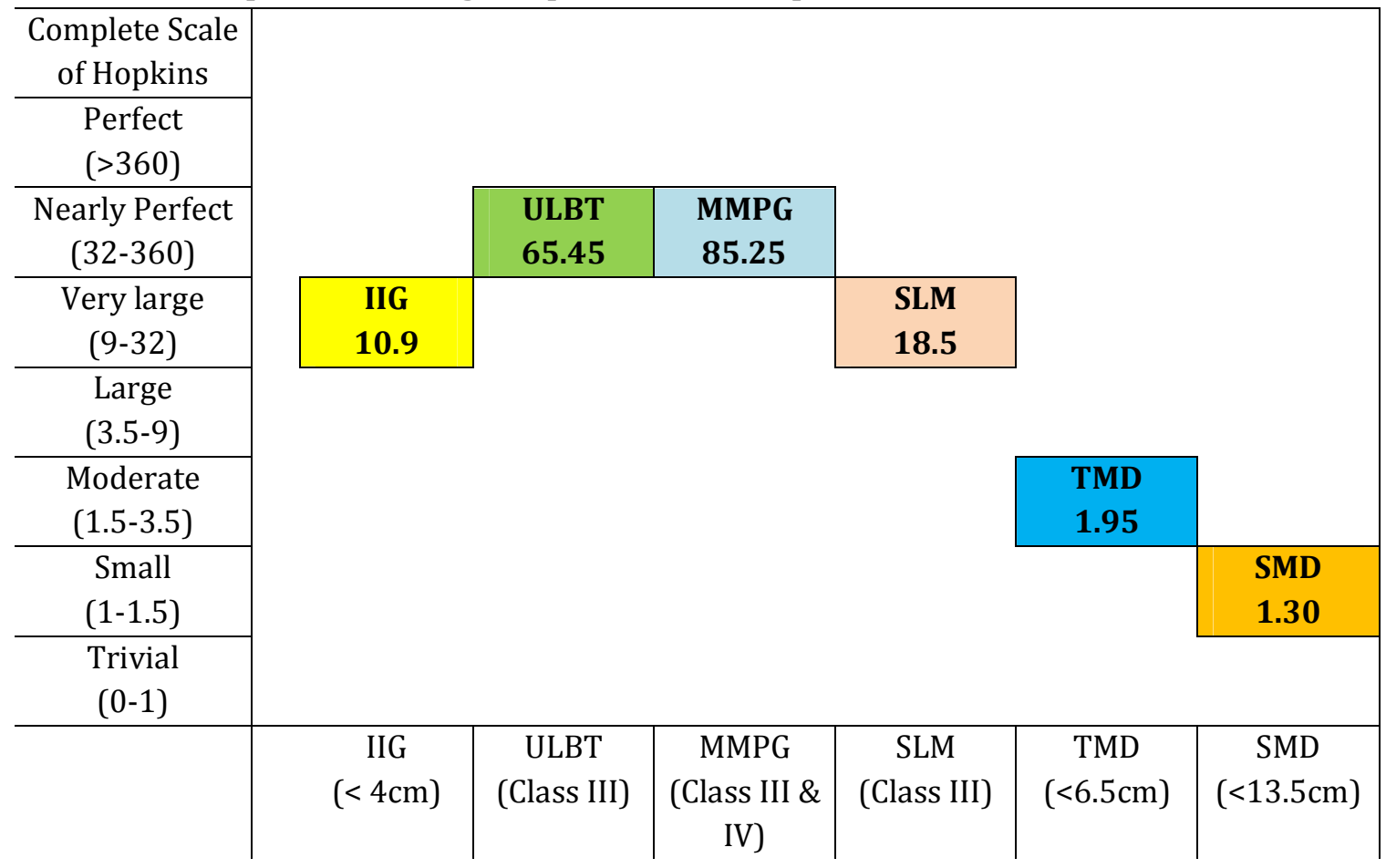

IIG= Inter Incisor Gap, MMPG= Modified Mallampatti Grading, ULBT= Upper lip bite test, TMD = Thyromental distance, $S M D=$ Sternomental distance, SLM= Subluxation of mandible 